\title{
Ploughshares into Swords - Colonial College Graduates in New Zealand
}

\author{
MARK DERBY
}

I have no doubt whatever in saying that all this country wants is a few hard-working men with a little capital, as there is plenty of land to be got of good quality and pretty cheap. Most of the very large sheep runs are being cut up into smaller ones ... If a fellow is steady and willing to work, I believe this is about the best country to come to. ${ }^{1}$

Writing from the 18,000-acre Pareora sheep station near Timaru at the height of the 1889 shearing season, young Englishman John Lodder exuded confidence in his choice of career. His ebullient account of his work routine and prospects was the very first such contribution to Colonia, the newly launched magazine of the British agricultural training school from which he had lately graduated. In its practical detail ('The shearing here is very different to the home shearing. It is all done in the wool shed'), and its optimism, Lodder's letter exemplified the Colonial College's dual mission of equipping well-born young men for farming life in Britain's colonies, and of strengthening the bonds of empire.

The need for such an institution had become widely apparent in Britain by the mid-1880s. A dramatic growth in the size and income of its middle classes had produced a bulge in the number of public school graduates, who found that the occupations to which they traditionally progressed - the upper reaches of the armed forces and the civil service, and the 'gentlemanly professions' - were over-supplied, and increasingly favoured entrance by merit rather than patronage.

As a result, a new class of 'supernumerary gentlemen' emerged. An 1897 magazine article characterized them as 'bright-eyed, clean-limbed, high-minded; ready for anything and fit for nothing'. ${ }^{2}$ Parents and educators agonized over the 'younger son question', and the consensus view was that emigration offered the greatest promise for educated young men who could no longer assume economic security and social position in their own country. Around one in ten of the three million who emigrated from Britain between 1880 and 1914 were 'gentlemen emigrants', and predominantly recent graduates of a public school or university. ${ }^{3}$

Although many of these classically-educated youths prospered and thrived in their adopted countries, a distressingly large proportion discovered that the curriculum they had studied, which had changed little in centuries, did not prepare them for the activities or society they encountered abroad. 'The unfortunate youth who is shipped out to a colony ... without having had any previous experience of farm life,' wrote one critic of this system, 'feels like a perfect fool, and is the butt of men who at home would have been in the position of his father's servants. ${ }^{4}$ 
Another warned sternly that:

the public-school-trained youth often fails to realize that he is no longer going among races accustomed to obey, but that he has to encounter a people entirely free from subservience to rank or wealth, a people intolerant therefore of dictation or condescension, in whose lives ... the distinction between class and class has for all practical purposes disappeared..$^{5}$

A consequence of such ill-prepared migration was regrettably apparent throughout the British colonies in the form of the remittance man, a wretchedly reduced character dependent on money from his family, and a living discredit to his class. An educational reformer characterized him as:

the most accomplished loafer in existence. The only money he ever makes is at pool or poker. The more decent sort ride or shoot. The majority drift from one saloon to another, and celebrate each cheque from home by a spell of bestial drunkenness. ${ }^{6}$

In 1887 a provincial New Zealand newspaper reported a promising development to address the 'younger son question' - the newly opened Colonial College in Hollesley Bay, Suffolk:

The students are beginning to come in quite as fast as the accommodation for them increases, and additional buildings are planned out. The training is to be mainly an outdoor one, and in that respect it differs from the other agricultural colleges in the United Kingdom ... Instruction in the elements of veterinary surgery, anatomy, and medicine will be given, as there is to be a resident veterinary surgeon. Bookkeeping, baking, brewing, plain cooking, and other domestic arts which a man often needs to know something of in a new country, will be among the indoor pursuits, as well as work in the dairy ... In short, the idea is to teach the young fellows to turn their hands to anything they are likely to have to do in the colonies ...

This unique institution was founded by a Suffolk gentleman farmer named Robert Johnson, with an established reputation as a philanthropist and ardent imperialist. He seeded support for the venture by circulating a proposal to influential acquaintances in Britain and abroad, and later published some of their endorsements of his plans, such as this response from an unnamed proponent:

There is absolute need for a crusade in favour of properly preparing our youths for that Emigration to the Colonies which is inevitable for so many of them; who if they are properly prepared for it will add not only to their individual happiness and comfort, but to the prosperity of the Empire ... ${ }^{8}$

In 1885 the Colonial College and Training Farms was registered as a limited company with Johnson as chairman. The headmasters of several leading public schools agreed to serve as patrons, along with the agents-general of favoured destinations including British Columbia, Cape Colony and several of the Australian colonies. New Zealand was represented by Sir Charles Clifford, a former Speaker of its House of Representatives.

The college was sited on almost 2000 acres of rich arable farmland bordering the River Alde and the south coast. Its light loam soil and sunny, low-rainfall climate eventually supported a 50-strong dairy herd of various breeds, several hundred black-faced Suffolk sheep, pigs, poultry, wood lots, a variety of experimental garden beds, several orchards, and plots of berries, roses, grapes and other perennial plants. Johnson, a capable amateur architect, 
designed some of its buildings which included a modern creamery, elaborate greenhouses, blacksmith's, wheelwright's and carpenter's workshops, and stables for the farm's renowned herd of Suffolk Punch draught horses.

Instruction toward a two-year certificate of competency typically involved about five hours daily of outdoor activity and two more of lectures. Experienced artisans gave training in metalworking, saddlery and other skills, with an emphasis on colonial practice. Students learned to ride with pommelled stock saddles rather than the flat English hunting saddle, and to build in timber rather than brick or masonry. Soil chemistry, geology, botany and land surveying were taught, and later cooking, hygiene and book-keeping, as the need for these became apparent from graduates' letters from abroad.

Tuition was expensive - about $£ 80$ a term for full board, with additional fees for special equipment and activities. Nevertheless, after opening in 1887 with just three students, the college attracted around 50 each year, and a total of over 700 by the turn of the century.

By its second year of operation, another New Zealand paper could report that:

about forty intelligent, prepossessing, well-developed young men, varying in age from 16 to 23, and thoroughly representative of the three kingdoms, are in residence, and in regular attendance at a diversified course of practical instruction to fit them for the vocation they have chosen. ${ }^{9}$

On completing that diversified course, College graduates faced a broad choice of destination in which to practise what they had learned. As well as the Anglophone colonies, the British empire then encompassed large areas of Asia and southern Africa and much of the Caribbean. 'Old Colonials', as the College graduates termed themselves, found work in all of these possessions, and also in the US, South America and a sprinkling of other 'foreign' destinations. Their distribution, however, was notably uneven. Over the 25-year lifetime of the college, very few Colonials opted for tropical dependencies such as those in the South Pacific, Africa or the West Indies, and not many favoured India, Ceylon or Burma. Instead, New Zealand, Australia, Canada and 'British South Africa' claimed the overwhelming majority, in proportions that varied according to their local economic conditions.

Between 1889, when the first crop of graduates departed, until 1893, the most popular destination was Canada, followed at some distance by Australia and New Zealand. For the next five years, as its 'long Depression' receded and dairy exports increased, New Zealand ranked first equal with Canada. Later, southern Africa was the most favoured but New Zealand remained popular. Ultimately, more than $20 \%$ of Colonial College graduates, or about 175 in total, chose to migrate to this most distant outpost of empire.

While many personal reasons undoubtedly influenced such a crucial decision, the exuberant reports from early arrivals to New Zealand such as John Lodder are likely to have persuaded numbers of later graduates to follow them. From 1889 the lively college magazine Colonia appeared three times a year. In many respects a typical school magazine, it duly reported the activities of the dramatic society, debating club and sports teams, included homilies from the principal, and solicited funds for further expansion. However, pride of place in each issue was given to an 'Old Students' Column', quoting letters received from far-flung sheep stations, cattle ranches, tea plantations and ostrich farms. ${ }^{10}$ 
In the same issue in which Lodder urged his fellow students to take up sheep farming, another Old Colonial, Thomas Rutherfurd, supplied a vivid account of 'A new chum's life in the land of the Maori and the Moa bird'. Writing of himself in the suave third-person from Makirikiri, Wanganui, he revealed that:

A new chum is often asked to do odd jobs out of ordinary working hours which the other men on the station would not condescend to do, but would rather give notice and leave the place. When he has finished he is permitted to sit with the 'boss' and his family for the rest of the evening: but he generally prefers the company of the men, and to sit in their 'whare' (Men's hut) smoking his well earned pipe ...

Sunday in New Zealand is 'washing day'. After breakfast the men collect pails of water, while one of them instructs the new chum in the art of a lighting a fire, over which a large boiler is suspended, and into this the men empty the pails, put in all their linen, and when the water begins to boil, pour in a little kerosene oil, and some pieces of soap. They then take out a long stick and stir the linen for a few minutes, take out the clothes, give them a little scrubbing, rinse them in cold water and hang them up to dry; this completes the washing.

Bush-firing and logging up is a job which is often given to a new chum, with another man to assist him. It is somewhat objectionable work as the smoke caused by the burning trees makes one's eyes water. 'Logging up' is generally done in the autumn when there are strong gales of wind blowing. The bush which has been felled in the winter is set fire to, and after a day or two when the ground is sufficiently cool for walking on, the still-burning logs are rolled together and piled up with rubbish, so that they may be burnt clean away and more ground cleared for grass. The logs are sometimes drawn together by bullocks. If the paddock is going to be ploughed, the stumps of the trees have to be dug out, which is sometimes done by means of a 'screw jack'.

Farmers in New Zealand do not indulge in many holidays, nor do they allow 'new chums' to do so. At Christmas they give them a few days, which they spend in visiting the towns around. On arriving in town a new chum gives himself up to innocent relaxation. After procuring some refreshment he strolls among the native men who salute him with 'Tinarkah Pakeha' [Tēnā koe, Pākehā] (good day, white man) and he amuses himself with chaffing the 'Wahinis' [Wāhines] (native women). In the evening he goes to the theatre, and finishes up with an oyster supper. ${ }^{11}$

Most of the New Zealand contributions to Colonia focus on the economics and practicalities of developing farmland in the backblocks, frequently land acquired at low rates on long-term government leasehold. J.G. Barthrop, writing from Hunterville in 1893, supplied detailed costs for felling, sowing and fencing his hosts' property, which:

was originally covered with dense bush; in fact I am told that in a great many places it was almost impossible to walk through on account of the dense undergrowth. The property is now all cleared except one or two little reserves and sown down with English grasses. ${ }^{12}$ 
Almost no correspondents express regret at the wastefulness of felling and burning native forest for grazing, although after clearing two acres in a week in the Kaipara district, A.H. Hewitt felt, 'it does seem a pity to cut down all those lovely trees and ferns and palms." Some wrote more specifically on matters such as 'My first pig-hunt', 'Wild dogs in New Zealand', 'Government surveying' and 'Some incidents of bush life'. These and the many other reports sent to Colonia by highly literate and intellectually curious would-be settlers comprise a substantial, precise and engaging picture of late-nineteenth-century rural life that has apparently evaded scholarly attention in this country.

While the correspondents' detailed and carefully costed reports on grass varieties, fencing, stock breeds and saleyard prices of are real historical value, it is their general and incidental observations that often provide the greatest interest. As a respite from his bush-clearing activities in the Kaipara, A.H. Hewitt took a trip to Warkworth:

to see the Cinematograph ... It is really wonderfully lifelike; they also had the phonograph there but that was not large enough, or anyhow did not give enough sound. I reckon that there are a good number of places in England where they have not seen the cinematograph, but everything new which comes out is almost certain to come round here. ${ }^{14}$

A contribution by W. Seavill, written in 1895, describes his working life on one of the country's most celebrated rural properties - Tutira, north of Napier, later the subject of a pioneering work of environmental history by its owner, Herbert Guthrie-Smith. After his first shearing, Seavill wrote that:

Maori shearers are employed, 16 and latterly 20 being on board. The 'fleece hos' and roll ups' were likewise Maoris, the 'missuses' and daughters of the shearers. The three chief things which have struck me with regard to Maoris are -1) their good temper, (2) their cruelty to animals, particularly to horses, and (3) their kindness to their children. ${ }^{15}$

The progress of former students, from the fresh-faced new chum to the sturdy settler, can be traced through successive issues of Colonia. On arrival at Knapdale Station in Gore in 1893, G.S. Smith found that he could:

live in the house with the 'boss', have my own room, horse and dogs and am on the whole very comfortable ... I keep the books, drive the engine for chaff cutting, and sometimes threshing, survey the contract ploughing etc, take out stores to the various camps, do a good deal of butchering, and of course have a lot of sheep work of every kind, besides many other things. ${ }^{16}$

W. Lovell, writing in the same year from Hawera 'in the heart of the Dairy District', confirmed that:

When a fellow comes out here he wants to be able to turn his hands to anything; now the other day I was asked to take a cord ( $1 \frac{1}{2} 2$ ton) of firewood (rata) into the town, 8 miles; I had never driven bullocks before, but I started with four bullocks. All the harness was two yokes, no ropes to guide them, but I got on splendidly, and when I got home my 'Boss' told me that I was the only new chum that he had ever seen that would do so. One never knows what he can do until he tries. ${ }^{17}$ 
Later issues proudly record the rewards for such enterprise. Writing from the Hakataramea Valley, south Canterbury, in 1898, B. Seth-Smith announced that he and a friend had recently bought 2700 acres further south at Ngapara, north Otago:

I have eight acres of splendid plantation round my new homestead, and capital stone stables and outbuildings ... It is surprising to me that more of the College fellows with a bit of capital, say $£ 3000$ or $£ 4000$, don't come out to this locality; there is a splendid opening, and I can guarantee that they will not find a more genial climate in all the world. ${ }^{18}$

Just a year after his arrival at Tutira, Hawkes Bay, W. Seavill and his brother acquired 4,000 acres of government leasehold land outside Ngaruawahia:

We are just now having a seven room wooden house completed, and in the meantime are living in a slab whare ... This district is going ahead very fast ... We have polo, football, and racing clubs, and as, with very few exceptions, our neighbours are a very nice set, we have nothing to complain of from a social point of view.

Thomas Rutherfurd, an energetic 'new chum' in 1889, could confirm his faith in his adopted country six years later by proudly informing the College, 'I have bought a small place of 100 acres, 25 miles from Masterton'. ${ }^{19}$ In 1900 he married and eventually produced six children, one of many College graduates to establish rural dynasties beyond their homeland.

In a worldwide survey of former students six years after his College opened, founder Robert Johnson could justifiably trumpet its successes:

... crossing the Pacific to New Zealand we find - from Dunedin in the south to the Bay of Plenty in the north - old Colonials so numerously settled that their influence in the development of the England of the Pacific should be felt (and we may trust beneficially felt) as years roll by. ${ }^{20}$

One student offered a similar celebration of progress in the form of a jaunty jingle:

Australia and Canada thrill with our fame

And the kangaroo leaps at the sound of our name

Cecil Rhodes has a plan which he thinks will take shape

To ship us by waggon-loads out to the Cape

While in distant New Zealand the Maories [sic] all say

'Please send us more students from Hollesley Bay!'21

A desire to expand the College's activities and influence was a recurrent theme from its inception. Within New Zealand, there was even talk of a transplanted local version of the College. A rural entrepreneur named Philip Perry, who had formerly worked on the vast Longbeach station in Canterbury and later taught at the Colonial College, was said to be arriving from Britain at the head of:

a party of 15 young men, all well born and possessing a considerable amount of capital, and also strongly backed by moneyed relatives. The scheme is to start a model farm and a training college in New Zealand, where the young men will remain and work and learn colonial ways, manners, and customs for two or three years, after which probably they may choose to settle for themselves on separate 
properties. Their destination is the Auckland province, and if possible their intended estate will be secured somewhere in the Waikato district. ${ }^{22}$

Nothing, however, seems to have come of this intriguing proposition.

In 1893, in one of a series of talks by colonial dignitaries, New Zealand's energetic young agent-general Westby Perceval addressed the College with the evident aim of encouraging more students to choose his country as the site for their ambitions. Robert Johnson introduced Perceval by describing New Zealand as 'the favourite colony' of the student body, and Perceval in turn praised the school as 'a most valuable colonisation agency'. ${ }^{23} \mathrm{He}$ made a spirited effort to correct the persistent impression that New Zealand was somehow part of Australia, and told his audience that 'You would be surprised, agreeably surprised, at the marvellous counterpart of the British Islands which we have there produced. ${ }^{24}$ His lengthy lecture, reprinted in full in Colonia, was illustrated by lantern slides, including one of a Māori chief, 'a gentleman of whom Mr Perceval jokingly spoke as belonging to the aristocracy of the country'. ${ }^{25}$

Robert Johnson was a fervent Empire loyalist, and his institution saw its mission as much wider than simply training a number of students to emigrate. The flags, badges and coats of arms of colonial destinations hung in its dining hall, and the names of Old Colonials appeared on plaques placed beneath the flags of the corners of the empire in which they had settled. The College flag itself combined the Union Jack with the Star of India, the Stars and Stripes (since Johnson and like-minded imperialists favoured the unification of a 'great Englishspeaking Community'), and the arms of Canada, South Africa and Australia (New Zealand being widely regarded, despite Perceval's efforts, simply as one of its provinces). ${ }^{26}$

In 1898 Colonia reprinted an article from the Economic Review that commended the College for upholding the bonds of empire at a time when most emigrants from Britain were choosing destinations outside the colonial possessions. 'Old Colonials' overwhelmingly preferred to settle in British colonies, said the writer, because they were better educated about their choice of destination:

There is no place in the British Isles, not even including the Colonial Office, where more accurate, reliable and up-to-date information about the colonies is possessed than at the Colonial College, and this information is constantly being added to and extended by letters received (and published in Colonia) from every part of the world.

The article urged official recognition and support for the College, 'first by being incorporated by charter as the Royal (or Imperial) Colonial College; and secondly, by receiving some financial aid to enable it to carry on still more successfully the work in which it is engaged. ${ }^{27}$ Robert Johnson would surely have welcomed this endorsement, as he had already been pressing for official support for the College for several years. He hoped to see it become formally allied with two existing bodies receiving state funding - the Royal Colonial Institute (later the Royal Commonwealth Society) and the Imperial Institute (later the Commonwealth Education Trust based in New Zealand House, London). With such backing, he believed, 'We foresee in our Colonial College a great Chartered Corporation carrying forward its 
beneficent work on a widely extended scale, facilitating colonisation and settlement in every clime, and forming throughout the world a great brotherhood of the best of England's sons. ${ }^{28}$

By the final years of the nineteenth-century, however, such a bold vision was already beginning to seem implausible. The cause of Imperial Federation, which promoted closer union between 'the mother country and her white self-governing colonies', struggled to withstand the impulse in many of those colonies for greater independence, and the Imperial Federation League, founded in London in 1884, survived less than a decade. ${ }^{29}$ In that short period the Colonial College, predictably, proved a dedicated supporter of the League's principles. The League secretary was invited to address the students, and a succession of articles in Colonia upheld its ambitions. However, the magazine also offered occasional indications that Imperial Federation was less effusively endorsed in the colonies themselves. J.D. Telford, writing from Mildura, Australia, in 1889, insisted that, 'Whatever the older colonists and the conservative press of Australia may think of the subject, the young Australians are decidedly blind to the glories of Imperial Federation. ${ }^{, 30}$

Robert Johnson continued to promote the aims of the Imperial Federation League well after its demise, but even within his own country his 'Greater Britain' sentiment was increasingly regarded as anachronistic. The Colonial College failed to win the official endorsement and financial backing he sought, and in the final months of the century, with the outbreak of the Boer War, one of its cherished 'bonds of empire' was irreparably damaged. The paradoxical result was that Old Colonials in several countries were reunited in an assertion of their patriotism.

In September 1899 W. Seavill, by then established in his own property in the Waikato ("we are doing very well, with every prospect of doing better'), noted that 'we are on the eve of war with the Transvaal, and wondering whether the Boers will give way at the last moment or not. ${ }^{31}$ The Boers held firm, and two months later W.T. Allen reported from Hawkes Bay that, 'New Zealand sent a contingent' to the Transvaal, 'but I could not say whether there were any of our fellows [i.e. Old Colonials] in it. ${ }^{32}$

In fact, Old Colonials from New Zealand, Canada, Australia and southern Africa itself enlisted for the South African War. No doubt they reached this decision for many of the same reasons - adventure, curiosity, patriotism, youthful enthusiasm - as recruits from other backgrounds. However, Old Colonials had also been suffused throughout their College training with the ideal of an Anglophone empire sustained into the twentieth-century by bonds of affinity and tradition. That ideal compelled their allegiance to maintaining British rule over obstinate Afrikaaners. The College's emphasis on horsemanship and many other outdoor pursuits further prepared its graduates for the unorthodox forms of warfare that had erupted in southern Africa. 'Since I turned my ploughshare into a sword', wrote one of them, 'I have been in many queer places and played many parts ... I can assure you I found all I learnt at the College of the greatest use to me'. ${ }^{33}$

Colonia's 'Old Students' Column' now mingled practical accounts of farming practice with stirring reports from the front lines. One of those, dated February 1900, described:

a scrap with the Boers at Sekwane; we killed 36 and wounded several, they only managed to hit 4 boys. They were lagered on the side of a kopje and commandeered the whole district, but still we drove them out and burnt their wagons. I must say 
they are very good in finding the range, why, the first shot they fired only fell short of about 10 yards, and we were 1200 yards away. It's a beastly feeling at first to be under fire, one feels excited and a creepy feeling comes over you. It was rather amusing to see the fellows bobbing their heads whenever a bullet whizzed over them, you can't help it, it comes natural. The Boers use the Mauser, it seems to be a decent gun, as you only hear a faint crack and the bullet hisses past you. We are moving down further south and will I suppose eventually reach Mafeking. ${ }^{34}$

John Lodder, the novice sheep farmer whose letter appears at the start of this paper, was one of the New Zealanders who took part in the conflict, although in his case only after persistent effort. Writing from Matamata in July 1900, he told Colonia, 'I tried very hard to get over to S. Africa with the different contingents leaving here, but the doctors would not accept me, owing to an attack of sciatica ... I am sure any of the students in S. Africa will be able to give a good account of themselves and be a credit to the dear old College. ${ }^{35}$ The following year Private Lodder travelled to South Africa with the seventh New Zealand contingent, joined the $7^{\text {th }}$ Mounted Rifles and eventually received a Queen's Service Medal.

Robert Johnson did not live to see the contribution made by his former students in this imperial crusade. His sudden death in 1901 signalled a steady downturn in the fortunes of the institution he created, and four years later it closed after recording a heavy financial deficit. The large property then changed hands and function a number of times until, in 1938, it became a borstal and prison farm whose inmates have included the Irish Republican bomber and writer Brendan Behan and the politician and novelist Jeffrey Archer. Nicknamed 'Holiday Bay' for its large number of escapes, Hollesley Bay remains the largest prison farm in Britain, and a stud farm for Suffolk Punch horses.

In the course of its relatively brief lifespan, the Colonial College supplied a significant cohort of well trained and highly motivated prospective settlers to New Zealand. The great majority of these appear to have remained and thrived in their new home, building careers not just as farmers but as veterinary surgeons, surveyors, sawmillers and other professionals. Some also held prominent posts in volunteer organizations - in the case of A.J. Stone-Wigg of Eketahuna, his local detachment of the Mounted Rifles. ${ }^{36}$ The College's ethos of imperial federation chimed with the philosophy of a unified empire that explained the exuberantly bellicose New Zealand response to the Anglo-Boer War.

At this historical distance, however, the College's most distinctive and valuable contribution to this country may be the body of first-person reports by New Zealand-based graduates that appear in its magazine. In their length, precision and vividness, these exceed most other accounts of rural life written by the hardworking, and generally less literate, settlers of this period, and constitute a rich body of material for scholarly investigation. It is hoped, therefore, that the notable omission of Colonia from the collections of any of the country's public libraries is an oversight that will be remedied as early as possible. 
${ }^{1}$ Colonia vol.1 (1889-91), 8-9.

2 Quoted in P. Dunae, 'Education, Emigration and Empire: the Colonial College 1887-1905', in J.A. Mangan, ed., Benefits Bestowed: Education and British Imperialism (Manchester and New York: Manchester University Press, 1989), 196.

${ }^{3}$ Ibid., p.195.

${ }^{4}$ T.C. Bridges, 'On Training Boys for Colonial Life', Empire Review, vol. XV (February 1908): 61.

${ }^{5}$ H.B. Gray, The Public Schools and the Empire (Michigan: University of Michigan, 1913), 20.

${ }^{6}$ Bridges, 63.

${ }^{7}$ Te Aroha News, 7 May 1887, 4.

${ }^{8}$ Colonia, vol.1 (1889-91): 5 .

${ }^{9}$ Thames Star, 23 February 1888, 2.

${ }^{10}$ Apart from the first issue, no copies of Colonia are held in New Zealand public collections. I am therefore indebted for research and advice in various countries to Patrick Dunae, Barbara Kearns, Mike and Enyde Webb, and especially to my brother, Nigel Derby.

${ }^{11}$ Colonia, vol.1 (1889-91), 24-26.

${ }^{12}$ Colonia, vol.5 (1898-99), 379.

${ }^{13}$ Ibid, 3.

${ }^{14}$ Ibid., 3.

${ }^{15}$ Colonia., vol.3 (1894-95), 236.

${ }^{16}$ Colonia, vol.2 (1892-933), 305-306.

${ }^{17}$ Ibid., vol.2 (1892-93), 228-229.

${ }^{18}$ Colonia, vol.5 (1898-99), 137-138.

${ }^{19}$ Colonia, vol.3 (1894-95), 380.

${ }^{20}$ Colonia, vol.2 (1892-93), 176.

${ }^{21}$ Colonia, vol.3 (1894-95), p.456.

${ }^{22}$ Otago Witness, 3 December 1896, 4.

${ }^{23}$ Colonia, vol.2 (1892-93), 428.

${ }^{24}$ Ibid.

${ }^{25}$ Ibid.

${ }^{26}$ Colonia, vol.6 (1900-01), 134.

${ }^{27}$ Colonia, vol.5 (1898-99), 19.

${ }^{28}$ Colonia, vol.5 (1898-99), 325.

${ }^{29}$ M.D. Burgess, 'Lord Rosebery and the Imperial Federation League, 1884-1893', New Zealand Journal of History, 13, 2 (October 1979):165.

${ }^{30}$ Colonia, vol.1 (1889-1901), 27.

${ }^{31}$ Colonia, vol.5 (1898-99), 331.

${ }^{32}$ Ibid., vol.5, (1898-99), 334.

${ }^{33}$ Colonia, vol.6 (1900-01),.217.

${ }^{34}$ Ibid., vol.6 (1900-01), 4.

${ }^{35}$ Ibid., vol.6 (1900-01), 135.

${ }^{36}$ Wairarapa Daily Times, 6 April 1907, 6. 